\title{
Elements in MOOC-based College English Learning Environment--Based on Biggs's 3P Model
}

\author{
Jun Song a, * \\ School of Foreign Languages, Southwest Minzu University, Chengdu 610041, China. \\ a, * Jun Song
}

Keywords: MOOC, Effective College English Learning Environment, Biggs's 3P Model.

\begin{abstract}
Under the background of the digital revolution era, college English teaching and learning are facing tremendous changes. Effective college English learning has long been overwhelmed by the focus on effective teaching in the traditional classroom teaching model. Based on Biggs's 3P Model of Learning, this paper discusses the essential elements in effective MOOC-based college English learning environments, deconstructs and reconstructs college English classroom.
\end{abstract}

\section{Introduction}

In recent years, new teaching models supported by informational environments such as MOOCs, flipping classrooms, and blended learning have emerged, and they have quickly become a hot topic and a focus of practice in college teaching reform. Over the years, college English teaching reform in China has achieved remarkable progress in the studies on how to teach. However, teaching, no matter how important, cannot take the place of learning. Changing students' learning style and advocating the effective learning is one of the focuses of the new reform of college English teaching. Much attention should be paid on the issue of what and how to learn to achieve the effective learning of students, thus furthering the present college English teaching reform in China to a new level. One of the ways to promote effective English learning is to construct the environment for effective English learning. Biggs's model conceptualizes the learning process as an interactive system of three sets of variables: the learning environment and student characteristics, students' approach to learning and learning outcomes. [1] Based on Biggs's 3P Model of Learning, this paper aims to discuss the essential elements in effective MOOC-based English learning environments, deconstructs and reconstructs college English classroom.

\section{Essential Elements in Effective MOOC-based English Learning Environment}

As a third-generation distance education, Massive Open Online Courses (MOOC) enable anyone to study anywhere for free in higher education. Understanding which factors account for students' effective learning in open online courses an important step toward is designing efficacious courses and improving open online learning. [2] In this section, the author attempts to explore essential elements in effective MOOC-based English learning environment based on Biggs's 3P Model.

John Biggs proposed 3P Model of Learning through scientific experiments. After nearly 20 years of revision, addition and refinement, Biggs turned the 3P learning model into a systematic learning process model. Biggs's (1993) 3P model of learning provides a useful context for understanding the importance and function of approaches to learning. The model proposes personal characteristics and environmental influences (presage factors) combine to create the approach a student uses in their learning (process factors), which in turn influences the learning outcomes (product factors) they are able to attain. [3] The 3Ps in the model refer to the presage, process and product factors of learning. Presage factors include personal characteristics of the student (prior knowledge, academic skills, personality) and learning environment characteristics (teaching methods, workload, and course structure). Process factors include the modality that students use to approach their learning (deep or surface). Product factors include the learning outcomes that students derive from the learning process 
(assessment scores, satisfaction and perceptions of transferable skills development). [4] Figure 1 shows a diagram of the 3P learning model.
Presage
Process
Product

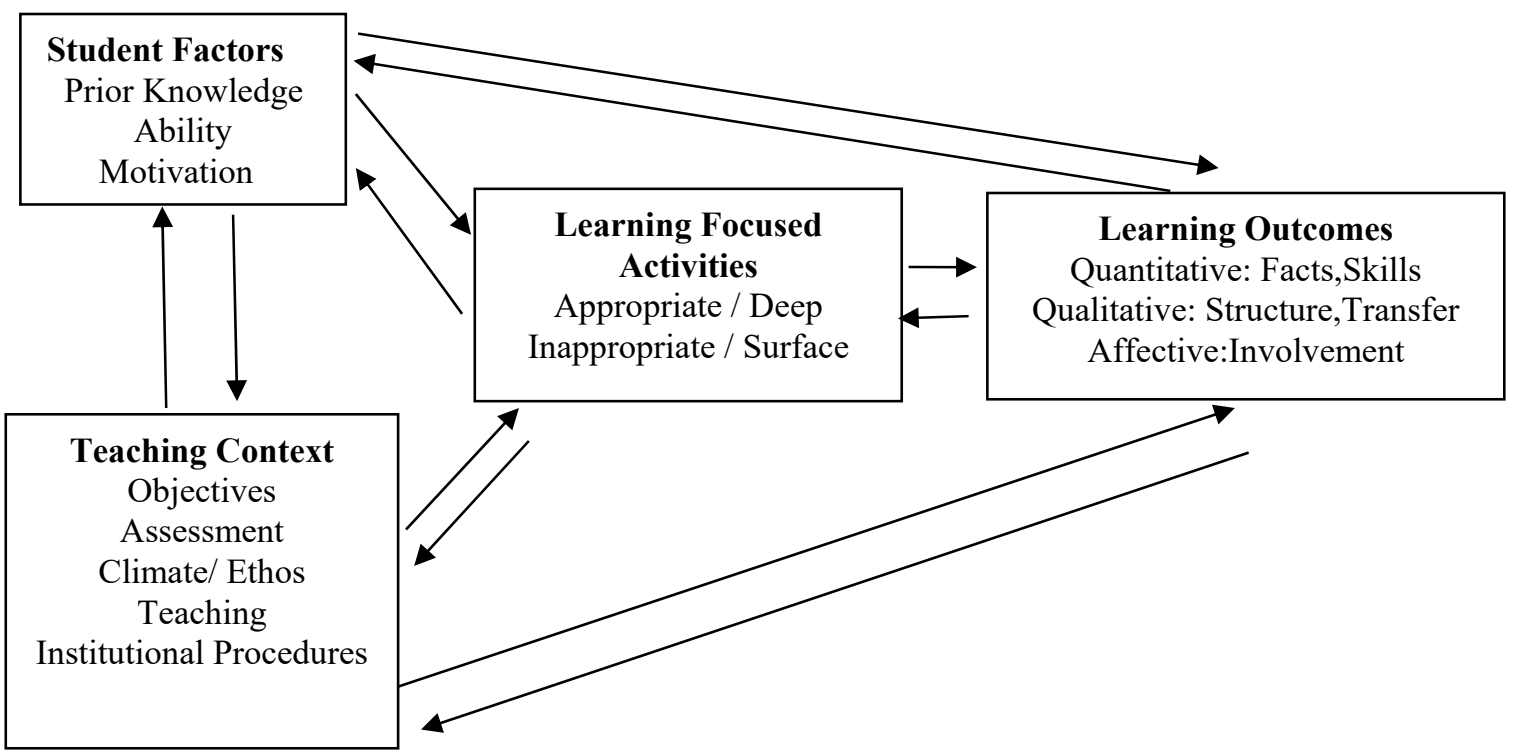

Fig. 1 Model of Teaching and Learning (John Biggs, 1993)

\subsection{Personal and Situational Factors (Presage Factors).}

Firstly, 'Presage' referred factors exist prior to learning, which is categorized into personal and situational elements. Personal factors are those characteristics the individual brings to the learning environment. Biggs (1987a) identified five types of personal factors, which may influence the approach to learning adopted by a student----prior knowledge, abilities, intelligence, personality and home background. [5] It is widely recognized that effective and efficient learning need to be individualized----personalized and learner-controlled. Situational factors are those factors creating the climate in which the learning tasks are undertaken. [6] Not only changes in predictive variables can determine changes in approach to study and, as a result, in outcomes, but outcomes, in turn, can affect the subsequent learning experiences and can act backwards by influencing process and predictive variables.

Individual student characteristics are related to how students engaged with MOOC activities and their completion of the course. For example, Kizilcec \& Schneider (2015) found that students' intentions and their level of intrinsic motivation were positively related to the extent to which students watched videos and their assessment completion in MOOCs. Similarly, students with high self-motivation were more engaged in MOOCs. Students' prior experiences with e-learning were found to be positively related to their participation level. Experienced students in networked learning participated at a higher level in MOOCs [7]. The other factor that presaged learning outcomes was situational factors, which refers to the external factor and learning environment the students experienced before the learning. Some of the student characteristics and situational factors were related to each other. For example, course assessments were related to student characteristics and some student characteristics may have affected the efficiency of tools used in MOOCs.

\subsection{Learning Approach Factors (Process Factors).}

Secondly, 'Process' involves students' approaches to learning and their perceptions of learning environment that is characterized by appropriate assessment, appropriate workload, clear goals and standards, and good teaching. [8] Richardson (2000) mentioned that these perceptions of learning environment are believed to influence the students' approaches to learning, which were generally categorized in deep and surface approaches. The student will choose a (deep or surface) strategy that will be determined specifically by the way he perceives the requirements of the learning environment. The deep approach involves in understanding the meaning of learning materials and surface approach 
involves simply 'scraping the surface' of the material being studied, without carrying out any deep processing of the material. A positive perception of learning environment (e.g. good teaching) is likely to improve deep and strategic approach to studying whereas negative perception (e.g. inappropriate workload) are likely to promote surface approach of student learning. [8] The deep approach was referred to self-understanding of the subject matter and the surface approach was related to coping with course requirements.

The normal expected approach to learning in MOOCs is to watch the video lectures, ask or answer questions in the forum concerning the difficult concepts of the lectures, then solve and submit assignments. In MOOC environments, students' learning approaches are oriented towards collaborative learning such as sharing, creating, and making mutual ways for learning instead of following individual paths. [9] Findings also showed that, apart from collaborative learning, queryand game-based learning also are highly preferred learning approaches in MOOCs. [10] The amount of collaborative and individual learning activities should be balanced since too many collaborative activities might make students feel frustrated and contribute to incomplete submissions that result in dropout. [11]

\subsection{Learning Outcome Factors (Product Factor).}

Thirdly, the final component of the 3P model of learning is the product factors, or more commonly referred to learning outcomes. In this case, the learning outcomes were specified into three variables: quantitative outcomes (how much the student has learned), qualitative outcomes (how the student has learned) and affective outcomes (students' attitudes towards their study experience and level of engagement in college life).[3] Biggs (1987a) suggests a learning task is successful if the outcome for the student includes positive feedback about the completed task, as well as an understanding of the purpose underlying the learning task.

It may not be useful to evaluate students' achievement with traditional metrics and methods. Some studies showed that being assignment-oriented and well-structured, having sequential course structure and well-designed assessments, task-oriented MOOCs, as well as the quality of materials (e.g., videos) are important portents of student success. [12] Moreover, instructor support (e.g., providing feedback) of student effort, which increases course engagement, may have a substantial positive impact on achievement in MOOCs. [13] Some studies pointed that participation, motivation, intention to complete the course, and level of course satisfaction are all related to students' achievement. [14]

\section{Conclusion}

With the advancement of college English teaching reforms, multimedia teaching models based on computers and classrooms and the concept of autonomous learning have gradually become popular. Considering students as central part in learning process, students learn better when they construct the knowledge by themselves, not what teacher intends should be learned. In this study, Biggs's 3P model is used as a way to provide organized explanations of factor involved in students' effective learning in open online courses. It is an important step toward designing efficacious courses and improving open online learning.

\section{Acknowledgements}

This work is supported by 2017 Southwest Manzo University Education \& Teaching Reform Research Project (No. 2017QN06).

\section{References}

[1]. Massimiliano Barattucci. Approach to Study as an Indicator of the Quality of Teaching and of Learning Environment: the Contribution of John Biggs. Journal of e-Learning and Knowledge Society. Vol. 13 (2017) No. 2, p. 77-78. 
[2]. Olga Pilli, Wilfried Admiraal. Students'Learning Outcomes in Massive Open Online Courses (MOOCs): Some Suggestions for Course Design. Journal of Higher Education. Vol. 7 (2017), p. 50-51.

[3]. Catherine Jones. Biggs's 3P Model of Learning: the Role of Personal Characteristics and Environmental Influences on Approaches to Learning. The Degree of Doctor of Philosophy. Griffith University. Australia. 2002. p.21-22.

[4]. Massimiliano Barattucci, Stefano Pagliaro, Dario Cafagna, Daniela Bosetto. An Examination of the Applicability of Biggs' 3P Learning Process Model to Italian University. Journal of e-Learning and Knowledge Society. Vol. 13 (2017) No. 1, p. 164-165.

[5]. Biggs, J.B. \& Telfer, R. The Process of Learning (2nd ed.). Sydney: Prentice Hall, 1987, p56-57.

[6]. Abraham, A. Effective Teaching and Learning: A Business Education Focus. In J. Sloman \& A. Beharrell (Eds.), Developments in Economics and Business Education Conference 2001 Proceedings. Bristol: University of Bristol, 2001, p. 1-29.

[7]. Greene, J.A.,C.A.,\&Pomerantz, J. Predictors of Retention and Achievement in a Massive Open Online Course. American Educational Research Journal. Vol.52(2015). 925-955.

[8]. Sovichea Vann. Learning Approaches and Learning Outcomes of the English University Curriculum: A Comparative Case of Cambodia and Thailand. Master's Degree. Stockholm University. 2016. P20-21.

[9]. Bali, M., Crawford, M., Jessen, R.L., Signorelli, P., \& Zamora, M. What makes a cMOOC community endre? Multiple participant perspective from diverse MOOCs. Educational Media International. Doi: 10.1080/09523987. 2015. 1053290.

[10]. Chang, R.I., Hung, Y.H., \& Lin, C.F. Survey of learning experiences and influence of learning style preferences on user intentions regarding MOOCs. British Journal of Educational Technology. Vol. 46 (2015) No. 15, p. 52-54.

[11]. Saadatmand, M., \& Kumpulainen, K. Participants ' perceptions of learning and networking in connectivist MOOCs. MERLOT Journal of Online Learning and Teaching. Vol.10(2014), p16-30.

[12]. Forsey, M., Low, M., \& Glance, D. Flipping the sociology classroom: Towards a practie of online pedagogy. Journal of Sociology. Vol. 49 (2013), p471-485.

[13]. Hernandez-Carranza, E.E., Romero-Corella, S.i., \& Ramirez-Montoya, M.S. Evaluation of digital didactic skills in massive open online courses: A contribution to the latin american moverment. Comunicar. XXII(2015). p81-89.

[14]. Castano-Garrido, C., Maiz-Olazabalaga, L., \& Garay-Ruiz, U. Design, motivation and performance in a cooperative MOC course. Comunicar. Vol. 22(2015). P19-26. 